\title{
DAMAGES UPON REPUDIATION OF A CONTRACT.
}

The repudiation of a contract before the time for performance by one of the parties to it has, or may have, two entirely distinct legal effects; In the first place, in England and in all but three of the United States, such repudiation amounts to a tender of a breach of the contract and if it is accepted as such by the other party it constitutes a so-called "anticipatory breach." 1 In the second place, in every State, even those not accepting the doctrine of anticipatory breach, ${ }^{2}$ notice of the repudiation may constitute a waiver of performance by the other side. ${ }^{3}$ If the notice is treated as a waiver of performance, the contract, to use the phrase commonly employed, is kept alive for the benefit of both parties. The effect on the amount of damages recoverable on a repudiation which constitutes a waiver of performance will be first considered.

I. Though notice of repudiation may be relied on as a waiver of further performance by the other party, and the latter may sue for a breach of the contract when the time comes for performance without himself doing any more acts in performance of his part of the contract, it nevertheless does not entitle the

I. Hochster v. De la Tour, 2 E. \& B. 678, 22 L. J. Q. B. 455; Roehm v. Horst, 178 U. S. I, 20 Sup. Ct. 780, 44 L. ed. 953, and cases cited; Hosmer v. Wilson, 7 Mich. 294, 74 Am. Dec. 716; O'Neil v. Supreme Council, 70 N. J. L. 410, 57 Atl. 463, and cases cited; Windmuller v. Pope, x07, N. X. 674, I4 N. E. 436; Girard v. Taggart, 5 S. \& R. 19; Davis v. Grand Rapids S. F. Co., 4I W. Va. 7x7, 24 S. E. 630; Ontario L. Co. v. Hamilton B. M. Co., 27 Ont. Ap. 346. Contra: Daniels v. Newton, Ir4 Mass. 530, I9 Am. Rep. $384 i$ and see I4 Harvard Law Review, 428 et seq.

2. Ripley v. McClure, 4 Ex. 345 (decided before the doctrine of anticipatory breach had been established in England); $P$. P. Emory Mfg. Co. $v$. Saloman, 178 Mass. 582, 60 N. E. 377 .

3. Cort v. Ambergate N. \& B. \& E. J. Ry., I7 Q. B. x27. Therefore if the other party refuses to accept the repudiation as a breach, or to act upon it as a waiver, but tenders performance at the time set in the contract, the repudiating party may retract his notice and accept performance and there will then be no breach. Ripley $v$. McClure, 4 Ex. 345 . Consequently if the market value has altered between the notice of repudiation and the time for performance, the other party's damages may be less than they would have been if he had accepted the notice as an anticipatory breach. Rhodes $v$. Cleveland R. M. Co., 17 Fed. 426. 
plaintiff to any greater compensation than he would get if the notice of repudiation had not been given before the breach. The repudiating party must, of course, compensate the other for such damage as he inflicts; but he does not by his wrong-doing subject himself to a forfeiture. The measure of damages recoverable against him for non-performance is the value of the contract at the time for its performance, or the socalled profit of the contract. This, generally speaking, is the difference between the contract price and the cost of full performance; ${ }^{4}$ in case of a contract for the sale of goods this will be equal to the difference between the contract price for the goods and their actual value at the time for delivery. ${ }^{5}$ In the case of a contract for the manufacture and sale of goods, when the breach consists in a refusal to accept the goods, it will amount to the difference between the contract price and the cost of manufacture. ${ }^{6}$ In many cases, however, the result of the notice of repudiation will be to stop performance by the plaintiff and in that way to cause a waste of his labor and materials. Whenever the result of the defendant's repudiation is to cause a waste of this sort to the plaintiff, compensation for this waste may be recovered in addition to the profit of the contract. ${ }^{7}$

Where a contract is performable in installments, such, for instance, as a contract for the delivery of goods in stated amounts from time to time, and there is a repudiation during the progress of the performance the damages for a breach consisting of the non-performance of subsequent installments

4. Brown v. Muller, L. R. 7 Ex. 319; Long v. Conklin, 75 Ill. 32; Goodrich v. Hubbard, 5I Mich. 62; McMaster v. State, 108 N. Y. 488, 15 N. E. 41 \%.

5. Cases where the seller repudiated: Leigh $v$. Patterson, 8 Taunt. 540; P. P. Emory Mfg. Co. v. Saloman, I78 Mass. 582, 60 N. E. 377; Leo Austrian \&o Co. v. Springer, 94 Mich. 343, 54 N. W. 50, 34 Am. St. Rep. 350. Cases where the buyer repudiated: Philpot v. Evans, 5 M. \& W. 475; Rhodes v. Cleveland R. M. Co., I7 Fed. 426; Kadish v. Young. 108 I1l. I7o, 48 Am. Rep. 548; Simons v. Ypsilanti Paper Co., 77 Mich. 185, 43 N. W. 864.

6. Hinckley v. Pittsburgh Steel Co., 12I U. S. 264; Worrell v. Kinnear Mfg. Co., 103 Va. 7I9, 49 S. E. 988.

7. Hale v. Hess, 30 Neb. 42,46 N. W. 26r; Dunnv. Allen, 55 App. Div. 637,67 N. Y. S. 218 . So where the defendant contracted with the plaintiff for ten-inch leather hose to be manufactured by the plaintiff, and repudiated the contract after the leather had been cut, and there was no sale for larger than nine-inch hose, the plaintiff was entitled to recover not only the profit that would have been made on the contract if it had been fully performed, but also the waste caused by cutting the leather down for nine-inch hose. City of Chicago v. Greer, 9 Wall. 726, I9 L. ed. 769. 
is to be estimated as at the time for the performance of each, and not as at the time for the performance of the last installment. If, for instance, between the time of the first breach and of the final breach the value of goods to be delivered fluctuates, the buyer who has failed to receive the installments due him cannot demand damages based on the value of the goods at the time the last installment should have been delivered, but he must be content with a basis of compensation which will give him the value of each installment at the time it should have been delivered. ${ }^{8}$ If, however, when delay occurs in the course of delivery, the parties by mutual agreement extend the time for delivery, so that when a breach finally happens, it is a breach of what has come to be an obligation at that time to deliver all the over-due installments, the damages are of course to be estimated as for non-delivery of all the articles at this agreed time. ${ }^{9}$

The question of most difficulty in a case where, in spite of the notice of repudiation, the olher party chooses to hold to the original contract, is whether the plaintiff may, if he chooses, proceed with the performance and charge the defendant in some way with the cost of the complete performance. If such a course does not enhance the damages he may clearly do so. This is the case where the contract is for the manufacture and delivery of goods readily salable in the market. The measure of damages for the breach of such a contract is the difference between the contract price and the cost of manufacture. This difference will not be increased by the act of the manufacturer in completing the manufacture. Indeed, it may be incumbent upon him to complete the manufacture notwithstanding the notice of repudiation. If, for instance, the notice should reach the manufacturer of such goods at the time when his product was incomplete, it would cause a waste of his labor and material to leave the product uncompleted. If he could stop at that time and charge the defendant with the waste caused by the incompletion of his product, he would thereby not diminish, but unnecessarily increase the damages to be paid by the wrongdoer; the waste of labor and material would be unnecessary, and for'this reason he could not compel the defendant to pay for it.

8. Brown v. Muller, L. R. 7 Ex. 3I9; Ex parte Llansamlet T. P. Co., L. R. 16 Eq. I55; Barningham v. Smith, 3 I L. T. Rep. 540; Delaware Eo H. C. Co. v. Mitchell, 92 Ill. App. 577; Hill v. Chipman, 59 Wis. 211, 18 N. W. 160 .

9. Ogle v. Earl Vane, L. R. 2 Q. B. 275; Ralli v. Rockmore, rrx. Fed. 874. 
In such a case, therefore, the manufacturer must complete the process of manufacture and thus enable himself to obtain the market price for his goods.

If, on the other hand, any further expenditure in performance of the contract after the reception of the notice of repudiation would be a mere waste, the plaintiff cannot incur such an expense, but must cease performance upon reception of the notice of repudiation. This doctrine was first clearly established in the leading case of Clarkv. Marsiglia. ${ }^{10}$ In that case it appeared that the defendant delivered. a number of paintings to the plaintiff to clean and repair, and after the plaintiff had commenced work upon the paintings the defendant desired him not to go on, as he had concluded not to have the work done. The plaintiff, notwithstanding, finished the cleaning and repairing of the pictures and claimed to recover for doing the whole work and for materials furnished; insisting that the defendant had no right to countermand the order he had given. The court said: "The defendant, by requiring the plaintiff to stop work upon the paintings, violated his contract and thereby incurred a liability to pay such damages as would include a recompense for the labor done and material used, and such further sum in damages as might, upon legal principle, be assessed for the breach of the contract; but the plaintiff had no right, by obstinately persisting in the work, to make the penalty upon the defendant greater than it would have otherwise been." And again: "In all such cases the just claims of the party employed are satisfied when he is fully recompensed for his part performance and indemnified for his loss in respect of the part left unexecuted; and to persist in accumulating a large demand is not consistent with good faith toward the employer." This decision has been almost universally followed. ${ }^{11}$

Occasion for the application of the principle of Clark v. Marsiglia usually occurs where the contract is for work to be done on the property of the defendant, ${ }^{12}$ or where a specific article is

I0. I Denio, 3 ז 7 .

xr. Rhodes v. Cleveland R. M. Co., I7 Fed. 426; Kingman v. Western $M f g$. Co., 92 Fed. 486,34 C. C. A. 489 ; American P. \& E. Co. v. Walker, 87 Mo. App. 503; Dillon v. Anderson, 43 N. Y. 23I; Heiser v. Mears, I20 N. C. 443,27 S. E. I17; Davis ข. Bronson, 2 N. Dak. 300, 50 N. W. 836 ; Danforth $v$. Walker, $37 \mathrm{Vt}$. 239, $40 \mathrm{Vt}$. 257; and cases cited in Williston's Pollock on Contracts, p. 349 .

12. Clark v. Marsiglia, I Den. 317; Davis v. Bronson, 2 N. Dak. 300, 50 N. W. 836 . 
to be made for the defendant which will be of use to no one else. ${ }^{18}$ But the same rule applies even in the case of a sale of ordinary goods salable in the market, when the plaintiff insists upon shipping the goods to the place of delivery, at considerable expense for carriage, although he has received notice that the goods will not be accepted by the purchaser. ${ }^{14}$

Even in the case of a contract of special value to the defendant, it might be less wasteful to continue to work after notice of repudiation than to stop work, though so far as the defendant is concerned the performance of the contract would be useless to him. This happens where the work for the defendant is only part of the entire process. So where the article to be delivered to the defendant was only a by-product of manufacture the plaintiff would of course not be called upon to stop the whole manufacture. ${ }^{15}$ This principle was involved in the interesting case of Martin $v$. Meles. ${ }^{16}$ This was a contract by which the plaintiff was to bring and prosecute a test case in defense of a patent. The suit was brought for the benefit of a large number of persons interested, who severally agreed to pay a share of the cost of services and expenses. After suit had begun, one of the parties gave notice to the plaintiff to discontinue on his behalf. In spite of the notice the plaintiff continued to prosecute the suit and charged the defendant with his portion of the expenses; although if the suit had been dropped upon receipt of his notice of repudiation a large part of the expenses would have been avoided. The court held that the plaintiff was not obliged, under the circumstances, to discontinue the suit at the defendant's request. Mr. Chief Justice Holmes said that the doctrine of Clark v. Marsiglia would not apply in such a case, where there was a common interest in the performance, and where what had been done and what remained to do probably were to a large extent inter-dependent.

In cases of repudiation not accepted as a breach of the contract the measure of damages is therefore not affected by the repudiation except so far as, according to the rule in Clark $v$. Marsiglia, the person notified must cease from further wasteful expenditure on account of the contract.

13. Kingman v. Western Mfg. Co., 92 Fed. 486,34 C. C. A. 489 ; American P. Eo E. Co. v. Walker, 87 Mo. App. 503.

I4. Sonka v. Chatham, 2 Tex. Civ. App. 312, 2I S. W. 948. But see Roebling v. Lock Stitch Fence Co., 130 Ill. 660, 22 N. E. 18.

15. Southern Cotton Oil Co. v. Heffin, 99 Fed. 339, 39 C. C. A. 546.

I6. I79 Mass. Ir4. 
II. Regarded as an offer for a breach of the contract, the repudiation, when accepted as such, becomes a complete breach and the injured party is at liberty to begin suit at once and to recover entire damages. The damages are to be assessed, of course, as of the date of the breach; nevertheless, they are to be a compensation for the loss caused by depriving the plaintiff of the benefit of the contract as it was originally made. The doctrine of anticipatory breach is not a doctrine which fictitiously moves the performance ahead to the time of the repudiation, and regards the repudiation as a failure to perform the contract. The anticipatory breach takes effect as a premature destruction of the contract rather than as a failure to perform it in its terms. The damage caused by such a premature destruction is, to be sure, due to the consequent failure to secure performance; but this is a failure to secure performance according to its original terms, that is, performance at the time and place when performance was required according to the terms of the agreement. Since the injury is the destruction of the contract, regarded as an article of property, the measure of damages is the value of such property at the time of its destruction; but since the value of a contract will ordinarily be determined by the benefit which its performance would confer, the exact measure of damages upon an anticipatory breach is in the ordinary case precisely the same as it would be if the repudiation were not accepted as a breach and the injured party brought suit, after the time of performance, for the non-performance at the time set. In other words, though the plaintiff sues at once for an anticipatory breach of the contract, his damages are to be assessed according to the cost of performance, not at the time of the breach, but at the time set for performance. ${ }^{17}$

Thus in the leading case of Roper $v$. Johnson ${ }^{18}$ it appeared that a contract by the defendant to deliver certain goods had been repudiated by him before the time for performance, and

17. Roper v. Johnson, L. R. 8. C. P. 167; Roehm v. Horst, I78 U. S. I, 20 Sup. Ct. 780; Missouri Furnace Co. v. Cochran, 8 Fed. 463 ; Cherry V. I. W. v. Florence I. R. Co., 64 Fed. 569, 12 C. C. A. 306; York D. M. Co. v. Lusk, 6 Kan. App. 629, 49 Pac. 788; Lee v. Briggs, 99 Mich. 487, 58 N. W. 477; Windmuller v. Pope, 107 N. Y. 674, I4 N. E. 436; Todd v. Gamble, 148 N. Y. 382,42 N. E. 982 ; Davis v. Grand Rapids S. F. Co., 41 W. Va. 7I 7 , 24 S. E. 630; Ontario Lantern Co. v. Hamilton B. M. Co.,27 Ont. App. 346. In case of a contract for the entire product of a manufactory, the profit made by other employment of the factory should be subtracted. Allen $v$. Field, r30 Fed. 64r.

r8. L. R. 8 C. P. 167 . 
that this repudiation had been accepted as a breach by the plaintiff, who brought suit at once. The court held that the measure of damages was the difference between the contract price and the market price at the time for performance. So in the case of Roehm v. Horst, ${ }^{19}$ where the purchaser repudiated a contract of sale before the time for delivery and the seller brought suit at once, it was held that the basis of damages in the absence of special circumstances was the cost of performance at the time fixed therefor by the contract.

Where the trial of the action is not had until after the time fixed by the contract for performance this rule will not result in any uncertainty as to the amount of damages; for market values at the time fixed for performance can be shown, and the amount of damages is therefore no more uncertain than it would have been if suit had been brought after the time fixed for performance. If, however, suit is brought and actually comes to trial before the time fixed for performance, there is an element of uncertainty, because the jury can tell only by conjecture what would be the actual cost of performance at the time set therefor. This, however, should be regarded as no objection to the application of the ordinary rule of damages. It is true that in such a case values at the time of breach, or rather at the time of trial, will be introduced in evidence and will probably form the basis upon which the jury will find the values at the date for performance; but such actual values are introduced in evidence not because values at the time of breach are of any importance in themselves, but merely as evidence to prove the probable values at the time of performance. It is also true that by this means the plaintiff may in fact get a larger verdict than he would have obtained if the trial had been held after the date for performance. This will happen, for instance, when the market unexpectedly rises or falls, as the case may be, between the time of trial and time of performance. But as Mr. Chief Justice Fuller said in the case of Roehm v. Horst, "Although he may receive his money earlier in this way, and may gain or lose by the estimate of his damage in advance of the time for performance, still, as we have seen, he has the right to accept the situation tendered him, and the other party cannot complain."

This is the generally accepted view; but in the important case of Masterton v. Mayor of Brooklyn ${ }^{20}$ a different view was

I9. 178 U. S. 1, 20 Sup. Ct. 780.

20. 7 Hill (N. Y.) 62. 
taken by the majority of the court. That was an action by a contractor who had agreed to deliver at the site of, the city hall in the city of Brooklyn all the marble that might be required for building the edifice. The contract was made in $\times 836$, and in I837 the city cancelled it. Full performance could not have taken place until 1840 . The action was brought before the performance could have been completed, but was not brought to trial until after the completion of the building. In order to find the profit of the contract it was of course necessary to determine the cost of the labor and materials required to deliver the marble at the building; and it was shown that. the. value of labor and materials fluctuated greatly between 1837 and 1840 . The majority of the court expressed the view that these fluctuations could not be shown, and that the profit of the contract must be estimated according to the value of labor and materials in 1837 , at the time when the contract was cancelled. Chief Justice Nelson said, "The damages are to be settled and ascertained according to the existing state of the market at the time the cause of action arose, and not at the time fixed for future performance." Judge Bronson concurred, saying, "This is the most plain and simple rule; it will best preserve the analogies of the law; and will be as likely as any other to do substantial justice to both parties." Judge Beardsley, on the other hand, said: "The expense of executing the contract must necessarily depend upon the price of labor and materials. If prices fluctuate during the period in question, that may be shown by. testimony. In this respect there is no need of resorting to conjecture; for all the data necessary to form a correct estimate of the entire expense of executing the contract can now be furnished by witnesses. If the cause had been brought to trial before the time for completing the contract expired, it would have been impracticable to make an accurate assessment of the damages. This is no reason, however, why the injured party should not have his damages.". These expressions of opinion by the judges in Masterton v. Mayor of Brooklyn are only dicta, for the case was sent back for a new trial on another point; and these dicta have not been very largely followed. ${ }^{21}$ Indeed, they apparently do not now represent the law in New York. ${ }^{22}$ The case has, how-

21. They were followed in Sullivan v. McMillan, 26 Fla. 543, 8 So. Rep. 450, and James H. Rice Co. v. Penn P. G. Co., 88 Ill. App. 407.

22. Windmuller v. Pope, 107 N. Y. 674, I4 N. E. 436; Todd v. Gamble, r48 N. Y. 382,42 N. E. 982 : St. Regis P. Co. v. Santa Clara L. Co., 173 N. Y. 149,65 N. E. 967 . 
ever, been frequently cited on this point, and more than one authority has treated the language of the majority.as a sound statement of the law. The argument is often put in this form. Damages are to be assessed as of the time of breach. Since the breach occurs at the moment of repudiation, damages are to be assessed as of that moment; and therefore when the assessment of damages involves an estimation of the value of commodities, that estimation should be made as of the time of the breach. This conclusion, however, is fallacious. It is true that the damage is to be assessed as of the time of the breach, but what is that damage? Suppose, for instance, we take a contract for the delivery of a thousand bushels of oats on the first of July, and suppose the contract is repudiated by the seller on the first of April; the loss thereby caused to the purchaser is not the loss at the time of so many bushels of oats. He had no right to the oats at that time by the original contract, nor did he gain a right to a thousand bushels of oats at that time by the repudiation of the original contract. His right at that time was a right to have one thousand bushels of oats delivered to him on the first of July; and it was the right to have the oats on the first of July, and not to oats on the first of April, that he lost by the repudiation. Now a right to a delivery of oats on the first of July is a right, the value of which, in the ordinary case, depends and can only depend upon the value of the oats to be delivered at the time for delivery. The value of oats on the first of April is utterly immaterial.

To this statement, however, there may be one exception. The thing lost on the first of April, as has been seen, is a contract for delivery of July oats. While the value of a contract is ordinarily measured by the value of the performance of it, that is not true in every case. There are certain contracts for the future delivery of commodities which have a present market value, not directly dependent upon the ultimate value of performance. For instance, in the case.just stated, if there were a produce exchange in which oats could be bought for future delivery, in other words, in which there was a market for contracts for the future delivery of oats, a contract for the delivery of oats on the first of July would, on the first of April, have a certain market value fixed by bargains on the floor of the produce exchange; and on general principles of the law of damages that market value would be taken as the value of the contract, and not the benefit ultimately to come from the performance of it. If then the defendant destroyed this contract on April 
first by a repudiation of it, the loss caused would be measured not by the value of the future delivery but by the market value of that contract on April first. It must be clearly noticed that this market value of the contract on April first is not the same thing as the difference between the contract price and the actual value of oats on April first. July oats may be quoted at a very different price from April oats; and the value of the contract would be the value of July oats on April first, not the value of April oats. In the case of an anticipatory breach of such a contract, therefore, the true measure of damages would seem to be the market quotation of goods of the sort for future delivery, and not the conjectural or even the actually proved profit arising from the contract in July. The value of anything for which there is a market is the market value, even though the actual economic worth of it may be different. 23

This doctrine, as will be seen, applies only in a narrow class of cases; namely, those where there is a market value for "futures." In several such cases, however, the courts, not noticing this distinction but seeing that the current quotations furnished the proper measure of damages, have attempted to work this out by some application of the rule denying recovery for avoidable consequences. It therefore will be necessary, in order to complete the consideration of this subject, to consider with some care the applicability of the rule of avoidable consequences to breaches of contract before the time for performance.

III. In the early case of Lee v. Paterson, ${ }^{24}$ where the notice of repudiation was not accepted as a breach, Bürrough, J., in holding that damages should be based on the market price at the time for performance, said: "The plaintiff was not bound to go into the market and buy. He never assented to rescind the contract." This has been thought by some courts to indicate that if he had accepted the repudiation as a breach, he might have been obliged to go in to the market and buy. It is entirely clear, however, that in using the word rescind Mr. Justice Bürrough did not have in mind the doctrine of anticipatory breach; which was not laid down by any English court until more than fifty years after his time. He had in mind the rescision of the contract in the true sense. In the later case of Brown $v$. Muller, ${ }^{25}$ where also notice of repudiation was not accepted as a

23. National Bank of Commerce v. New Bedford, 75 Mass. 257.

24. 8 Taunt. 540 .

25. L. R. 7 Ex. 319 . 
breach, the court said distinctly that the plaintiff need not go into the market and buy other goods on the defendant's account. In Roper $v$. Johnson, ${ }^{28}$ where the repudiation was accepted and suit brought at once, the court clearly expressed the view, obiter, that the plaintiff was under no obligation to go into the market and attempt to get a new contract. In the later case of Roth $v$. Taysen, ${ }^{27}$ however, the court took a different view. In that case the buyer of goods repudiated his contract at a time when the market was obviously falling. The court held that the seller was bound to sell the goods at once upon accepting the notice as a breach, and that he could charge the defendant with only such damages as would have accrued if he had sold within a reasonable time. The court in this case relied on the special circumstance that by a clause in the contract either party, upon breach by the other, might, after written notice, resell or repurchase on the other's account. In view of this clause it seems clear that it was the plaintiff's duty, in accordance with the doctrine of Clark $v$. Marsiglia, to sell on the defendant's account. In the later case of Nickol $v$. Ashton, ${ }^{28}$ the court expressed obiter its concurrence in this decision upon the general principle that it was the duty of the injured party to mitigate his damages.

In this country actual authorities on the point are few. In the case of Kadish $v$. Young, ${ }^{29}$ where the plaintiff refused to accept notice of repudiation as a breach, the court held that the plaintiff was not bound to make a forward contract for the purchase of property. In the case of Missouri Furnace Co. $v$. Cochran, ${ }^{80}$ where after receiving notice of repudiation the buyer at once brought suit and immediately made a forward contract for the purchase at the then market rate, which afterwards and before the time set for performance declined, the court held that the measure of damages was to be governed by the actual market price at the time fixed by the contract for delivery, and that he could not get damages based upon the contract for future delivery which he had made at the time of repudiation. There was no claim in this case that it was unwise for the plaintiff to make a second contract. ${ }^{80}$ In Hinckley $v$ Pittsburgh.

26. L. R. 8 C. P. 167.

27. I2 T. L. R. 2 r r, 73 L. T. Rep. 628.

28. 1900,2 Q. B. 298.

29. ro8 Ill. r70, 48 Am. Rep. 548.

30. 8 Fed. $4 t^{t ;}$.

30a. The decision in this case seems questionable, because the making of the forward contract appears to have been a reasonable attempt to avoid further loss. 
Steel Co., ${ }^{31}$ where the plaintiff had contracted to manufacture and deliver steel rails and the defendant had cancelled the order before the time for delivery, the court held that the plaintiff need not mitigate the damages by completing the manufacture of these particular rails and selling them to others, but that the measure of damages was the difference between the contract price and the cost of manufacture. In Roehm $v$. Horst ${ }^{32}$ the court appeared to take it for granted that the damages would be mitigated by any circumstances of which the plaintiff ought reasonably to have availed himself, and added, "He may show what was the value of the contract by showing for what price he could have made sub-contracts." The contract was for the sale of hops, a commodity in which futures were bought and sold, and the buyer repudiated. The suggestion of the court therefore is that since "futures" in hops could be bought in the market the market price of the futures furnished a measure of the value of the contract. The court evidently does not mean to suggest that it was the duty of the plaintiff to mitigate the damages by entering into a future contract. Indeed, as the plaintiff was the seller he could have mitigated his damages in the sense of the English decisions only by selling for future delivery, not by buying. The suggestion of the court was neither that he should sell nor that he should buy, but that the value of his contract was determined by subtracting from the contract price the cost at the time of breach of a similar contract for the future delivery of hops. In other words, this case is an application of the principle already explained, that where a contract has a market value at the time of the breach that value is to be the basis of recovery, and not the profit of the contract at the time fixed for delivery. It thus appears that the doctrine of Roth $v$. Taysen finds no support in the Supreme Court of the United States.

On principle it seems perfectly clear that the repudiator of a contract cannot under any circumstances call upon the other party to make forward contracts for his benefit. Indeed, the very statement of the case would seem to show the unfairness of it. Assuming that the market is obviously rising or obviously falling and that it is desirable for one party or the other to protect himself by entering into a contract for future performance, it would seem that the burden and the risk should be thrown upon the wrong-doer rather than the innocent victim of the breach. To say that the wrong-doer, by his repudiation of the contract,

3I. 122 U. S. 264

32. 178 U. S. I, 20 Sup. Ct. 780. 
can put upon his victim the risk of making a future contract and thus put him at the mercy of a jury, who if he makes a losing contract may say that it was not reasonable, or if he fails to make a contract and the market turns to his advantage may say that it was unreasonable not to make it, is to give to the wrong-doer all the benefits and none of the burdens of the other party's skill and foresight in forecasting the market. But there are other objections fully as conclusive as this one. If the injured party is skillful enough to anticipate the market and to make a beneficial contract, he should be able to retain for himself all profits that arise from the exercise of his skill. Suppose, for instance, $A$ buys oats for future delivery and the seller repudiates before delivery. Suppose thereupon $A$, believing that the market will continue to rise, makes a hundred contracts for the future delivery of oats to himself. If the market continues to rise he realizes a large profit on each of these contracts. Surely he is entitled to the benefit of such profits. To say that one of these contracts should be applied, not to his benefit, but to make up for the loss caused by the breach of the first contract, is to put it in the power of a repudiator, when the market is obviously going against him, to gain the advantage of the other party's skill and credit. The fact is that the repudiator is entitled to the benefit of no contract of the other party except such as the other party could not have made but for the repudiation. If, for instance, an employer wrongfully discharges his servant before the term of employment has expired and the servant obtains other employment the employer is entitled to the benefit of such other employment, because but for the discharge the servant would not have had his time to dispose of in this way. If, however, all the beneficial contracts made by the wronged party could equally have been made if the repudiator had performed his contract, then the other party is entitled to the benefit of the repudiated contract and to the benefit of all others as well. This principle is well illustrated by the case of Wolf $v$. Studebaker. ${ }^{88}$ In that case it appeared that the defendant agreed to let his farm to the plaintiff, receiving as rent one-half the profits; and when the time came he refused to give possession to the plaintiff. Being sued for the breach the defendant claimed the right to mitigate damages by showing what the plaintiff had earned in other employments during the season. This was held inadmissable. To put the matter in another way, a person whose contract has been broken by the other party is obliged to take steps to avoid consequential dam-

33. $65 \mathrm{~Pa} .459$. 
ages, but not direct. In point of fact, direct damage is impossible to avoid; and the rule which forbids the recovery of compensation for avoidable consequences of an injury does not cover the direct loss in any way.. Now the loss of the profit of the contract is the direct loss, and no steps which the party could take could possibly diminish the loss of the actual profit of the contract caused by the breach of it.

If, however, the plaintiff would be entitled to consequential damages by reason of the fact that he had given notice to the other party that in case of breach of the contract consequential damages would happen, then it is quite true that if notice of repudiation is given and is accepted as a breach he must take steps to avoid such consequential damages. If, for instance, the plaintiff makes a contract for the purchase of goods for future delivery, giving notice of a profitable contract of resale, and the seller r'epudiates before the time for performance, the buyer, if he accepts the repudiation as a breach, must buy elsewhere, if he can, to avoid the consequential loss of the resale; if he could buy elsewhere and fails to do so he cannot charge the defendant with the loss of the resale. Even in such a case he cannot be called upon to take steps to avoid the consequential loss if he refuses to accept the notice of repudiation as a breach; for no one is obliged to act upon a mere threat of wrong. ${ }^{34}$ It is only after a cause of action has arisen that the party is called upon to act. Joseph H. Beale, Jr.

34. P. P. Emory Mfg. Co. v. Saloman, 178 Mass. 582,60 N. E. 377 . 